УДК 159.9

DOI: https://doi.org/10.33120/ssj.vi46(49).156

\author{
Мирончак Катерина Володимирівна \\ кандидат психологічних наук, старший науковий співробітник \\ лабораторії соціальної психології особистості, \\ Інститут соціальної та політичної психології НАПН України, \\ м. Київ, Україна \\ ORCID ID 0000-0002-1378-0494 \\ katerynamyronchak@gmail.com
}

\title{
ВТРАТИ ПІД ЧАС ПАНДЕМІЇ: РІЗНОВИДИ ТА ОСОБЛИВОСТІ ПЕРЕЖИВАННЯ
}

\begin{abstract}
Завданням дослідження було окреслити процеси ускладнення особистісних втрат людини під час поширення пандемії COVID-19 та виокремити актуальні для цього періоду різновиди втрат. Основні методи дослідження - частотний аналіз, синтез, узагальнення. Наслідки переживання втрат визначено як психологічні дефіцитарні стани, які руйнують цілісність життєвого світу особистості. 3'ясовано, що за умови несвоєчасного опрацювання втрати, використання практики іiі уникнення і заперечення виникає ціла низка можливих негативних наслідків: зменшення індивідуальних ресурсів особистості, зниження загальної якості життя, послаблення функціонування психологічних механізмів захисту та контролю, уповільнення життєвої активності, активація різноманітних “мутацій" та викривлення в процесах самоідентифікації, формуванні життєвих планів і перспектив, фіксація на об’єкті втрати і неможливість іiі прийняття, загострення кризових станів. Визначено основні різновиди втрат, які переживає людина під час пандемії. Виділено три найпоширеніші види втрат: втрата можливостей, на які очікували і сподівалися, втрата впевненості в майбутньому та втрата спокою. Визначено помірно поширені втрати: втрата відпочинку, грошей, хорошого сну, втрата впевненості у собі та втрата значущого спілкування. 3'ясовано, що під час пандемії імовірність втрати довіри до інших $є$ значно вищою, ніж втрата довіри до себе. Представлені результати щодо актуальних різновидів втрат під час пандемії та особливості їх проживання можуть бути використані фахівцями для своєчасної діагностики типу втрати, а прицільне опрацювання ii негативних наслідків дасть змогу інтегрувати біль від втрати в цінний, екзистенційний досвід особистості. Перспективою подальших досліджень $\epsilon$ розроблення системи заходів і методів соціально-психологічного супроводу особистості, що переживає той чи інший різновид втрати.
\end{abstract}

Ключові слова: переживання втрати; різновиди втрат; пандемія COVID-19; негативні наслідки; ізоляція.

\section{LOSSES DURING THE PANDEMIC: VARIETIES AND FEATURES OF EXPERIENCE}

\author{
Kateryna V. Myronchak \\ Ph.D. in Psychology, Senior Research Associate, \\ Laboratory of Social Psychology of Personality, \\ Institute for Social and Political Psychology, NAES of Ukraine, \\ Kyiv, Ukraine \\ ORCID ID $\underline{0000-0002-1378-0494}$ \\ katerynamyronchak@gmail.com
}

The purpose of the study was to outline the processes of complication of personal losses during the spread of the COVID-19 pandemic and to identify the types of losses relevant for this 
period. The main research methods are frequency analysis, synthesis, generalization. The consequences of loss experiencing are defined as psychological deficit voids that destroy the integrity of the individual's lifeworld. It is found that in case of belated processing of loss, of its avoidance and denial practices there are a number of possible negative consequences: reduction of individual resources, reduction of overall quality of the life, weakening of psychological mechanisms of protection and control, slowing down of vital activity, activation of various "mutations", and distortion in the processes of self-identification, perception of space and time, the formation of life plans and prospects, fixation on the object of loss, and the impossibility of its acceptance, exacerbation of crisis states. There are identified the current types of losses experienced by a person during a pandemic. There are three most common losses: loss of opportunities that were expected $(53.4 \%)$, loss of confidence in the future $(44.8 \%)$, and loss of serenity $(39.7 \%)$. Moderately spread losses are also determined: loss of the rest (29.3\%), loss of money (24.1\%), loss of good sleep $(22.4 \%)$, loss of self-confidence (22.4\%), and loss of meaningful communication $(22.4 \%)$. It is found that during the pandemic, the probability of trust in others loss (15.5\%) is much higher than the loss of trust in oneself $(1.7 \%)$. The presented results on the actual types of losses during the pandemic and the peculiarities of their experience can be used by specialists for well-timed diagnosis of the loss type, and targeted treatment of its negative consequences will integrate the pain of loss into valuable, existential personal experience. The prospect of further research is to develop a system of measures and methods of socio-psychological support of the individual experiencing one or another type of loss. isolation.

Keywords: loss experience; types of losses; COVID-19 pandemic; negative consequences;

Постановка проблеми. У період різноманітних карантинних обмежень $є$ загроза накопичення психологічного стресу через його пролонгованість у часі та невизначеність часових перспектив завершення пандемії. За версією видавців тлумачних словників англійської мови Collins English Dictionary, словом 2020 року названо “локдаун”, що походить 3 тюремної лексики і вживається в контексті заборони ув'язненим виходити 3 камер за порушення. “Ув'язнений вірусом” 2020-й рік вносить корективи в значення цього слова, що здебільшого представлене у свідомості людей як необхідний захід для збереження здоров'я. Попри значне смислове навантаження на означене поняття за тривалих умов соціального дистанціювання й ізоляції відбувається зменшення індивідуальних ресурсів особистості, зниження загальної якості життя, послаблення функціонування психологічних механізмів захисту та контролю, уповільнення життєвої активності. Унаслідок численних втрат відбуваються різноманітні “мутації” та викривлення в процесах самоідентифікації, сприйманні простору та часу, формуванні життєвих планів і перспектив тощо. Усе це може загострювати чи поглиблювати депресивні стани, стани тривоги, неспокою, апатії до повсякденного життя, депресії, посттравматичні розлади.

Люди здебільшого намагаються уникати болючих тем, застосовуючи механізми захисту щодо власних страхів. Через неготовність відкрито говорити про свої переживання людина відчуває негативні наслідки активного використання практик уникнення i заперечення втрати (підтримка ілюзорності цілісності вже зруйнованої дійсності, фіксація на об'єкті втрати і неможливість ії прийняття, виникнення панічного страху, брак готовності і ресурсів для розмов про наболіле, загострення кризових станів тощо). Такий фоновий емоційний тиск може спричиняти серйозні психологічні проблеми. Втрата, хоч і не завжди за своїм призначенням, однак за своєю природою $є$ дефіцитарним явищем. Тобто те, що “випадає” (зникає, втрачається) з нашої психічної реальності через різні причини, природно утворює тимчасову (пролонговану, або фіксовано стійку) порожнечу. Коли людина переживає втрату, яка супроводжується відчуттям спустошеності, їй хочеться швидше цю порожнечу чимось заповнити, поєднати розірвані втратою частини життя, відновити неперервність життєвого шляху, повернути рівновагу в життя, “стабілізуватися”.

Поняття дефіцитарності більше прижилося в психіатрії, де воно позначає мінуссимптоми, появу шкідливої симптоматики, вади, недосконалості психічної діяльності на різних iї рівнях. Якщо така негативно заряджена симптоматика досить довго зберігається, то 
3 часом, природно, вона може провокувати виникнення того чи іншого психічного дефекту. Якщо термін “дефект” розуміти широко, то йдеться про функціональний дефект (порушення основних функцій життєдіяльності особистості), що за умови несвоєчасного опрацювання може переростати в тяжкі, невротичні стани. Ступінь вираженості негативної симптоматики може варіюватися в досить широкому континуумі: від не дуже помітного послаблення загального життєвого тонусу, зниження рівня самоефективності та працездатності до серйозних психічних порушень, що руйнують цілісність особистості.

Як зазначає Девід Кесслер, у горя, як і у болю, немає ієрархії - біль є біль (Kessler, 2019). Інтенсивність болю від втрати людина переживає так, як вона сама ії, відповідно, оцінює і суб'єктивно переживає. Одні втрати можуть викликати у нас сильний гнів і розпач, інші ж можуть пройти майже непоміченими. Кожен рухається через переживання втрати у своєму ритмі, своїм унікальним способом (Mancini, \& Bonanno, 2011). Часто людина схильна замовчувати свої переживання щодо втрати, боячись осуду, нерозуміння чи помилкових надмірних очікувань з боку оточення, тим самим підвищуючи внутрішній емоційний тиск цих непрожитих, непроявлених, заархівованих емоцій. Через бажання якомога швидше позбутися болісних переживань з приводу втрати, витіснити їх багато людей блокують процес пошуку сенсу цієї втрати, що в разі своєчасного опрацювання дало б змогу інтегрувати біль від втрати в найбільш глибокий, екзистенційний досвід особистості.

Аналіз останніх досліджень і публікацій, виокремлення нерозв'язаних частин загальної проблеми. Більшість психологічних досліджень втрати пов'язані зі смертю близької людини, з ії психологічними наслідками, зокрема переживанням страждань, болю, горя, скорботи (С. Бохнер, Д. Боулбі, Ф. Ю. Василюк, А. Лорі, Р. А. Неймеєр, С. Паркес, Х. Г.Прігерсон, Д. Хелл, Н. Хоган). Низка наукових досліджень також показали, що переживання важких психологічних станів, зокрема переживання горя, актуалізуються не лише після фізичної втрати (смерті), а й унаслідок втрат з різною модальністю (соціальних, психологічних, географічних), що якісно змінюють життя людини, наприклад, таких як розлучення або втрата роботи (Рapa, Lancaster, \& Kahler, 2014).

Останнім часом дослідження втрат, пов'язаних 3 пандемією

COVID-19, привертають все більшу увагу. Особливо цікавими видаються дані щодо впливу пандемії на психічне здоров'я людини (Rajkumar, 2020). Коли йдеться про пандемію COVID19, очевидними є втрати людей, які безпосередньо уражені вірусом або пережили страждання від смерті близьких людей. Однак більшість людей переживають іншого роду втрати, які торкаються колективних процесів горювання. Останні представлені як наслідок втрати звичного, нормального стану, спричиненої частково заходами стримування, придушення тих чи інших індивідуальних потреб. Ідеться про втрату нормальності своєї усталеної буденності і горювання з приводу того, що вже неможливо повернути. Усе це може призвести до відчуття порожнечі і навіть втрати сенсу життя (Berinato, 2020; Taha, 2020). Деякі дослідники припускають, що заходи повної ізоляції тривалістю понад 10 днів можуть призвести до посттравматичного стресового розладу (Schippers, 2020) і мати низку серйозних наслідків для психічного здоров'я людини (Fegert, Vitiello, Plener, \& Clemens, 2020; Schippers, 2020). Загалом, дослідники, насамперед китайські (Wang et al., 2020), вказують на значно вищий рівень стресу, тривоги, паніки, депресії, порушення сну та симптомів посттравматичного стресового розладу.

Мета статті - виділити актуальні різновиди втрат під час пандемії серед українського населення і з'ясувати особливості їх переживання.

Виклад основного матеріалу дослідження. Ми провели онлайн-дослідження за допомогою відкритої платформи Google Forms. Головним методичним інструментарієм стала анкета-опитувальник, сконструйована 3 відповідних блоків. Перша частина анкети містить питання, що дають змогу дослідити втрати, які є актуальними на сьогодні, визначити емоційне тло в процесі переживання втрати, зони ураження втратою життєвого світу та способи відновлення втрачених ресурсів. Друга частина опитувальника спрямована на дослідження особливостей соціально-психологічного супроводу під час переживання втрати. 
До онлайн-вибірки увійшли 58 респондентів (48 жінок, 10 чоловіків) 3 досить широким віковим діапазоном (від 19 до 70 років).

У цій статті висвітлено лише окремі частини дослідження, а саме - поширеність різновидів втрат під час пандемії. Одним із ключових питань анкети було питання "Яку саме втрату за останні пів року Ви переживали (переживаєте) в умовах пандемії?" Досліджуваним пропонувалося вибрати відповідь із 20 запропонованих варіантів або варіант 3 відкритою відповіддю, якщо із запропонованих конструкцій респондент не знайде відповідного для себе. Відповідей можна було давати декілька, з урахуванням того, що модальність втрат досить різна і людина може переживати одночасно декілька їх видів. До остаточного списку різновидів втрат увійшли ті, які найчастіше траплялися під час психотерапевтичної практики, зокрема роботи з людьми, які постраждали тією чи іншою мірою від початку пандемічного періоду. Ідеться про участь у волонтерському проєкті “ОНЛАЙН-КОЛО”, присвяченому темі психологічного здоров'я під час пандемії COVID-19 (Слюсаревський, 2020). Нижче графічно представлено розподіл різновидів втрат, які $\epsilon$ актуальними сьогодні (рис.).

Першу позицію займають втрати можливостей, на які респонденти очікували і сподівалися $(53,4 \%)$. Коли чогось дуже хочеш, мрієш про це, очікуєш моменту реалізації і втілення задуманого, а в результаті нічого не отримуєш, з'являється розчарування. Розчарування - це одна 3 найпоширеніших емоційних реакцій людини на ситуації, коли очікування і реальність не збігаються, а часом навіть суперечать одне одному. Розчарування, як показує психотерапевтична практика, $є$ поверхневим шаром почуття. За цим шаром часто приховані відчуття внутрішнього застою чи безпорадності, нездатності змусити події відбуватися так, як хтось того хоче. Тобто втрата можливостей, на які очікували i сподівалися, $є$ найпоширенішим різновидом втрат під час пандемії, що $є$ досить серйозним фрустраційним фактором, який часто супроводжується почуттями роздратованості і гніву через невирішені проблеми, невиконані обіцянки, зруйновані плани, заблоковані цілі, відтерміновані завдання, “заморожені" бажання або нереалізовані потреби. Емоційний супровід втрати можливостей, на які очікували, має негативний аспект ще й через те, що людина в ситуації вимушеної, контрольованої пролонгованої паузи нічого вдіяти не може, а докладання будь-яких зусиль видається марним або неефективним. Втрата важливих, а часом і ключових у житті людини можливостей може поглиблювати відчуття розчарування, образи, невдоволеності собою та іншими, пригніченості і зневіри щодо появи в майбутньому нових шансів і перспектив.

На другому місці - втрата впевненості в майбутньому (44,8\%). В умовах пандемічної небезпеки і ймовірної загрози смерті впевненість у майбутньому поступається більш сильній емоції - страху перед майбутнім. Задля того щоб вижити, страх активує природний інстинкт виживання в організмі, спонукаючи нас до дії, мобілізує в організмі стани настороженості і надмірної напруженості. У сучасному суспільстві страх перед майбутнім зростає під тиском перевантаженого стресом життя. Такими стресовими факторами можуть бути абсолютно різні ситуації, події, які безпосередньо не піддаються контролю особистості. Невизначеність i “невідомість" щодо майбутнього лише поглиблюють страх, який може стати непідконтрольним особистості, змінюючи і підпорядковуючи під себе ії життєві цілі, траєкторії, наміри і плани. Боячись наслідків важкопрогнозованих ризиків, людина радше буде обирати стратегію уникання всього сумнівного, небезпечного, незнайомого, чужорідного. Таким чином, люди схильні замикатися в обмеженому колі своїх напрацьованих i перевірених життєвих завдань, намагаючись не виходити за межі дозволеного і звичного, уникаючи усіляких змін, ризиків, експериментів, викликів, не наважуючись змінитись або приміряти ролі, про які вони потайки продовжують мріяти, а відтак страждають через неможливість їх реалізації. Це може призвести до посилення відчуття власної безпорадності, знедоленості і нездатності творити своє життя, як того бажає сама людина, до чого вона тяжіє і прагне. Втрата впевненості в майбутньому посилюється також через низку страхів, які в період пандемії виходять на перші позиції: страх захворіти 
на термінальну хворобу, страх залишитися без грошей або джерела доходу (грошових втрат зазнали $24,1 \%$ опитуваних), страх втратити свою теперішню роботу, страх втратити кохану людину. Тобто втрата впевненості в майбутньому підкріплена не так реальними втратами, як страхом потенційних втрат.

\section{Яку саме втрату за останні півроку Ви переживали (переживаєте) в умовах пандемії? (58 респондентів)}

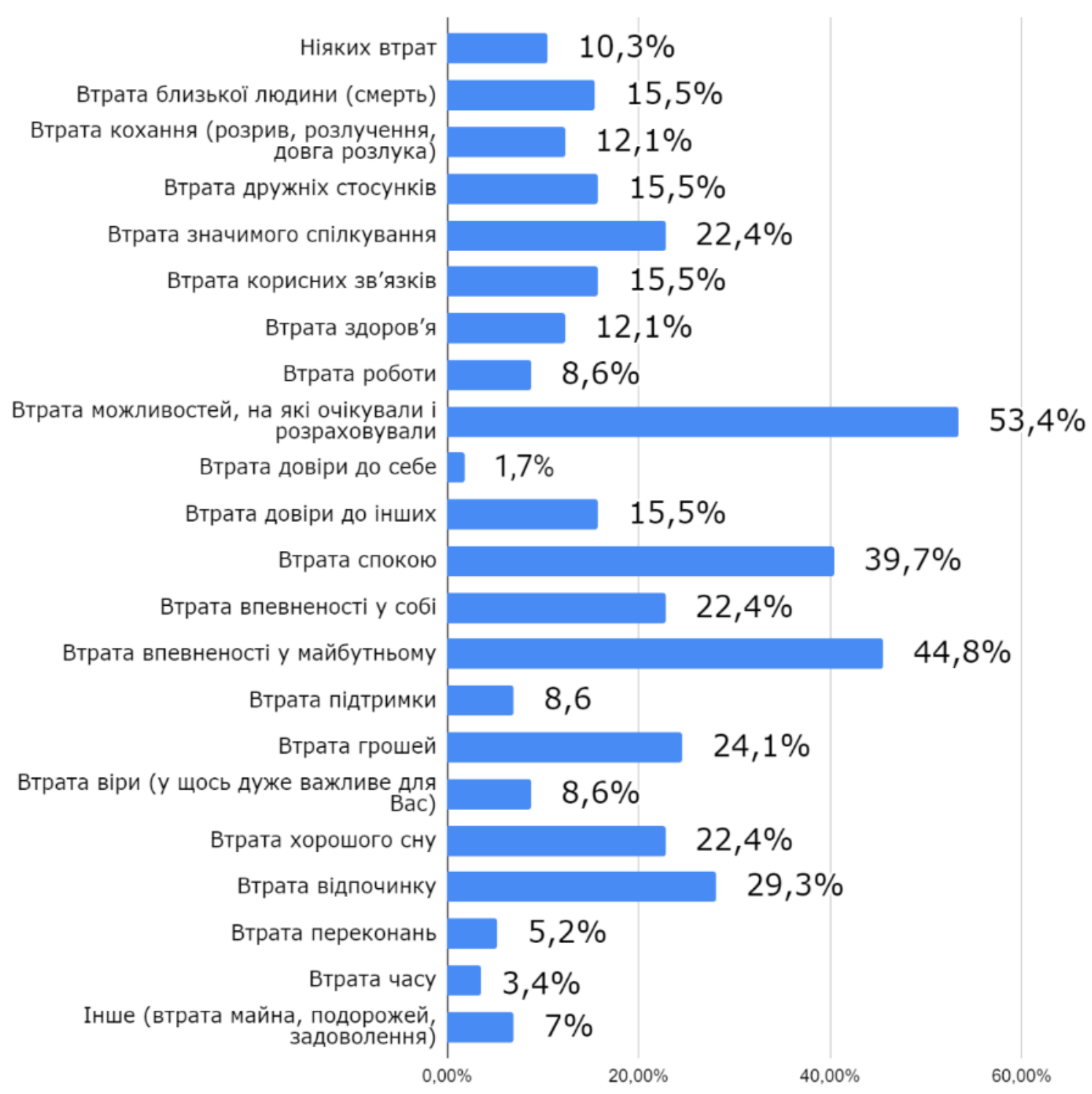

Рuc. Розподіл різновидів втрат за період з травня по листопад 2020 р.

Трійку лідерів замикає втрата спокою (39,7\%). Очевидно, що кожна людина час від часу переживає кризові періоди в житті, які супроводжуються втратою спокою. Однак цей різновид втрати $\epsilon$ особливо небезпечним в умовах пандемії через свою тривалість. Абсолютно природно хвилюватися через ті чи інші причини, коли це ситуаційно, локалізовано в часі. I зовсім інший ефект від хвилювання, коли стан неспокою стає хронічним, щоденно відтворюючи у свідомості чи підсвідомості людини ситуацію можливої небезпеки чи загрози. Хронічний стан неспокою - це тривалий, неконтрольований стрес, що заважає організму повернутися до нормального стану. Через неможливість швидко 
стабілізуватися і відновитися після вичерпання життєвих резервів (ресурсів) організму (фізичних чи психічних) людина з часом починає помічати серйозні порушення здоров'я та гормональних функцій, механізмів саморегуляції окремих життєво важливих систем. Поширеною симптоматикою хронічного неспокою є порушення сну (втрата хорошого сну $22,4 \%$ ), підвищена тривожність, відчуття слабкості і безпорадності (втрата впевненості у собі - 22,4\%), проблеми 3 концентрацією уваги, погіршення пам'яті, зниження швидкості мислення, знервованість, бажання все контролювати, нездатність розслабитися і відпочити (втрата відпочинку - 29,3\%).

Окремо торкнемося втрати значущого спілкування $(22,4 \%)$. Як зазначалося вище, жорсткі форми соціальної ізоляції, наприклад необхідність дотримання дистанції в декілька метрів від інших людей, брак спілкування, уникання будь-яких контактів, можуть призводити до вкрай неприємних наслідків. Найбільш вразливі - люди похилого віку. Багато хто 3 них 3 віком зменшує свою активність (фізичну і соціальну), коло їхніх близьких звужується, імовірність смерті близьких друзів та членів сім’ї зростає. Попри загальну тенденцію підвищення рівня інформаційної і технологічної компетентності серед людей поважного віку все ж значна іхня частина рідко $є$ активними користувачами соціальних мереж, куди перемістилася велика частина соціального життя. Не маючи необхідних цифрових навиків для підтримання спілкування, а часом і бажання освоювати їх, люди у віці схильні почуватися більш самотніми і покинутими. Масштабне дослідження впливу соціальної дистанції на смертність провела психолог Джуліанна Холт-Ланстад. У 2015 р. вона 3 колегами здійснила метааналіз 70 досліджень 3 понад 3,4 мільйонами учасників. За ними спостерігали в середньому протягом 7 років. За цей час імовірність смерті тих, хто почувався самотніми, виросла на 26\%, тих, хто мав мало соціальних контактів, - на $29 \%$, а тих, хто жив самотньо, - на 32\% (Holt-Lunstad et al., 2015). Деякі люди витримують соціальну ізоляцію краще за інших. Однак не варто ігнорувати нові онлайн-форми соціальності, які допоможуть пережити ізоляцію з меншими втратами.

Звернімо відтак увагу на ще одну цікаву особливість у розподілі різновидів втрат (див. рис.). Виявилося, що під час пандемії люди частіше втрачають довіру до інших (15,5\%), ніж довіру до себе (1,7\%). 3 одного боку, втрата довіри до інших може бути похідною від переживання інших втрат у сфері міжособистісних стосунків (втрата кохання - 12,1\%, втрата дружніх стосунків - 15,5\%, втрата корисних зв'язків - 15,5\%). 3 другого боку, у ситуаціях хаосу, невизначеності і невідомості людині властиво покладатися на себе і власні сили як на щось відносно унормоване, стійке і знайоме. Адже ситуація пандемії в Україні - це порівняно нова, екстремальна, ризикогенна ситуація, в якій людина може проявлятися порізному, неочікувано для себе і для інших. Відомо, що в екстремальних ситуаціях, коли захисні соціальні ролі не спрацьовують належним чином, людина схильна діяти і поводитися інстинктивно, необдумано, імпульсивно. Таким чином, у нетиповій ситуації може проявитися нетипова поведінкова реакція, здатна шокувати, розчарувати, обурити чи, навпаки, здивувати, приємно вразити. В екзистенційному підході такі кризові або складні життєві ситуації (наприклад, висока мортальна загроза під час пандемії) є неодмінною умовою для прояву справжньої природи людини і можливостей іiі зростання. А от яка природа проявиться, буде залежати від того, який внутрішній зміст і наповненість у їі носія.

Висновки та перспективи подальших досліджень. Наслідки переживання втрат визначено як психологічні дефіцитарні стани, які руйнують цілісність життєвого світу особистості. Визначено актуальні різновиди втрат, які переживає людина під час пандемії. До першої трійки увійшли: втрата можливостей, на які очікували і сподівалися, втрата впевненості в майбутньому та втрата спокою. З'ясовано, що під час пандемії імовірність втрати довіри до інших є значно вищою, ніж втрата довіри до себе. Найбільш вразливі щодо втрати значущого спілкування за умови соціальної ізоляції люди похилого віку, схильні переживати одночасно різні види втрат.

Перспективою подальших досліджень $є$ розроблення системи заходів і методів соціально-психологічного супроводу особистості, що переживає втрату. Своєчасна 
діагностика різновиду втрат та опрацювання їх негативних наслідків дасть змогу інтегрувати біль від втрати в найбільш глибокий, екзистенційний досвід особистості, спрямований на особистісне зцілення і посттравматичне зростання.

\section{Список використаних джерел}

Слюсаревський, М. М. (2020). “ОНЛАЙН-КОЛО”: досвід психологічної підтримки і допомоги населенню під час пандемії COVID-19. Вісник Національної академії педагогічних наук України, 2(1). Взято 3 https://visnyk.naps.gov.ua/index.php/journal/article/

Berinato, S. (2020). That discomfort you're feeling is grief. Harvard Business Review. Retrieved from https://hbr.org/2020/03/that-discomfort-youre-feelingis-grief.

Davis, S. (2020). Perezhivanie, Art, and Creative Traversal: A Method of Marking and Moving Through COVID and Grief. Qualitative Inquiry. Retrieved from https://journals.sagepub.com/doi/ $10.1177 / 1077800420960158$

Fegert, J. M., Vitiello, B., Plener, P. L., and Clemens, V. (2020). Challenges and burden of the coronavirus 2019 (COVID-19) pandemic for child and adolescent mental health: a narrative review to highlight clinical and research needs in the acute phase and the long return to normality. Child Adolesc. Psychiatry Ment. Health, 14, 1-11. doi: 10.1186/s13034-020-00329-3

Holt-Lunstad, J., Smith, T. B., Baker, M., Harris, T., \& Stephenson, D. (2015). Loneliness and social isolation as risk factors for mortality: a meta-analytic review. Perspectives on psychological science, 10(2), 227-237.

Kessler, D. (2019). Finding Meaning: The Sixth Stage of Grief, New York: Scribner.

Mancini, A., \& Bonanno, G. (2011). Loss and grief: The role of individual differences. In S. Southwick, B. Litz, D. Charney, \& M. Friedman (Eds.), Resilience and Mental Health: Challenges Across the Lifespan (pp. 189-199). Cambridge: Cambridge University Press. doi:10.1017/CBO9780511994791.015

Papa, A., Lancaster, N. G., and Kahler, J. (2014). Commonalities in grief responding across bereavement and non-bereavement losses. J. Affect. Disord, 161, 136-143. doi: 10.1016/j.jad.2014.03.018

Rajkumar, R. P. (2020). COVID-19 and mental health: A review of the existing literature. Asian Journal of Psychiatry, 52, 102066. http://dx.doi.org/10.1016/j.ajp.2020.102066 Retrieved from https://www.sciencedirect.com/science/article/abs/pii/S1876201820301775

Schippers, M. (2020). For the greater good? The devastating ripple effects of the lockdown measures. SSRN [Preprint]. doi: 10.2139/ssrn.3612622

Taha, N. (2020). Veel stress en angst om coronacrisis: "Mensen ervaren emoties die sterk lijken op rouw". Algemeen Dagblad. Retrieved from https:/www.ad.nl/binnenland/ veel-stress-en-angst-omcoronacrisis-mensen-ervaren-emoties-die-sterk-lijken-oprouw://www.google.com/ (September 25, 2020).

Wang, C., Pan, R., Wan, X., Tan, Y., Xu, L., Ho, C. S., \& Ho, R. C. (2020). Immediate psychological responses and associated factors during the initial stage of the 2019 coronavirus disease (COVID-19) epidemic among the general population in China. International Journal of Environmental Research and Public Health, 17,1729.http://dx.doi.org/10.3390/ijerph17051729. Retrieved from https://www.mdpi.com/1660-4601/17/5/1729/htm

\section{References}

Berinato, S. (2020). That discomfort you're feeling is grief. Harvard Business Review. Available at: https://hbr.org/2020/03/that-discomfort-youre-feelingis-grief (September 25, 2020). (in English)

Davis, S. (2020). Perezhivanie, Art, and Creative Traversal: A Method of Marking and Moving Through COVID and Grief. Qualitative Inquiry. Retrieved from https://journals.sagepub.com/doi/10.1177/ 1077800420960158. (in English)

Fegert, J. M., Vitiello, B., Plener, P. L., and Clemens, V. (2020). Challenges and burden of the coronavirus 2019 (COVID-19) pandemic for child and adolescent mental health: a narrative review to highlight clinical and research needs in the acute phase and the long return to normality. Child Adolesc. Psychiatry Ment. Health 14, 1-11. doi: 10.1186/s13034-020-00329-3 (in English)

Holt-Lunstad, J., Smith, T. B., Baker, M., Harris, T., \& Stephenson, D. (2015). Loneliness and social isolation as risk factors for mortality: a meta-analytic review. Perspectives on psychological science, 10(2), 227-237. (in English) 
Kessler, D. (2019). Finding Meaning: The Sixth Stage of Grief, New York: Scribner. (in English)

Mancini, A., \& Bonanno, G. (2011). Loss and grief: The role of individual differences. In S. Southwick, B. Litz, D. Charney, \& M. Friedman (Eds.), Resilience and Mental Health: Challenges Across the Lifespan (pp. 189-199). Cambridge: Cambridge University Press. doi:10.1017/CBO9780511994791.015 (in English)

Papa, A., Lancaster, N. G., and Kahler, J. (2014). Commonalities in grief responding across bereavement and non-bereavement losses. J. Affect. Disord. 161, 136-143. doi: 10.1016/j.jad.2014.03.018 (in English)

Rajkumar, R. P. (2020). COVID-19 and mental health: A review of the existing literature. Asian Journal of Psychiatry, 52,102066.http://dx.doi.org/10.1016/j.ajp.2020.102066 (in English)

Schippers, M. (2020). For the greater good? The devastating ripple effects of the lockdown measures. SSRN [Preprint]. doi: 10.2139/ssrn.3612622 (in English)

Sliysarevskyy, M. M. (2020). "ONLAIN-KOLO": dosvid psykholohichnoi pidtrymky i dopomohy naselenniu pid chas pandemii COVID-19. Visnyk Natsionalnoi akademii pedahohichnykh nauk Ukrainy, 2(1). Retrieved from https://visnyk.naps.gov.ua/index.php/journal/article/. (in Ukrainian)

Taha, N. (2020). Veel stress en angst om coronacrisis: "Mensen ervaren emoties die sterk lijken op rouw". Algemeen Dagblad. Available at: https://www.ad.nl/binnenland/ veel-stress-en-angst-omcoronacrisis-mensen-ervaren-emoties-die-sterk-lijken-oprouw://www.google.com/ (September 25, 2020). (in Dutch)

Wang, C., Pan, R., Wan, X., Tan, Y., Xu, L., Ho, C. S., \& Ho, R. C. (2020). Immediate psychological responses and associated factors during the initial stage of the 2019 coronavirus disease (COVID-19) epidemic among the general population in China. International Journal of Environmental Research and Public Health, 17,1729.http://dx.doi.org/10.3390/ijerph17051729. (in English) 